\title{
Global satellite analysis of the relation between aerosols and short-lived trace gases
}

\author{
J. P. Veefkind ${ }^{1}$, K. F. Boersma ${ }^{1,5}$, J. Wang ${ }^{2}$, T. P. Kurosu ${ }^{3}$, N. Krotkov ${ }^{4}$, K. Chance ${ }^{3}$, and P. F. Levelt ${ }^{1,5}$ \\ ${ }^{1}$ Royal Netherlands Meteorological Institute, De Bilt, The Netherlands \\ ${ }^{2}$ University of Nebraska-Lincoln, Lincoln, Nebraska, USA \\ ${ }^{3}$ Harvard-Smithsonian Center for Astrophysics, Cambridge, Massachusetts, USA \\ ${ }^{4}$ Goddard Earth Sciences and Technology Center, University of Maryland Baltimore County, Baltimore, Maryland, USA \\ ${ }^{5}$ Eindhoven University of Technology, Eindhoven, The Netherlands
}

Received: 5 July 2010 - Published in Atmos. Chem. Phys. Discuss.: 11 August 2010

Revised: 18 November 2010 - Accepted: 1 February 2011 - Published: 14 February 2011

\begin{abstract}
The spatial and temporal correlations between concurrent satellite observations of aerosol optical thickness (AOT) from the Moderate Resolution Imaging Spectroradiometer (MODIS) and tropospheric columns of nitrogen dioxide $\left(\mathrm{NO}_{2}\right)$, sulfur dioxide $\left(\mathrm{SO}_{2}\right)$, and formaldehyde (HCHO) from the Ozone Monitoring Instrument (OMI) are used to infer information on the global composition of aerosol particles. When averaging the satellite data over large regions and longer time periods, we find significant correlation between MODIS AOT and OMI trace gas columns for various regions in the world. This shows that these enhanced aerosol and trace gas concentrations originate from common sources, such as fossil fuel combustion, biomass burning, and organic compounds released from the biosphere. This leads us to propose that satellite-inferred AOT to $\mathrm{NO}_{2}$ ratios for regions with comparable photochemical regimes can be used as indicators for the relative regional pollution control of combustion processes. Indeed, satellites observe low AOT to $\mathrm{NO}_{2}$ ratios over the eastern United States and western Europe, and high AOT to $\mathrm{NO}_{2}$ ratios over comparably industrialized regions in eastern Europe and China. Emission databases and $\mathrm{OMI} \mathrm{SO}_{2}$ observations over these regions suggest a much stronger sulfur contribution to aerosol formation than over the well-regulated areas of the eastern United States and western Europe. Furthermore, satellite observations show AOT to $\mathrm{NO}_{2}$ ratios are a factor 100 higher over biomass burning regions than over industrialized areas, reflecting the unregulated burning practices with strong primary particle emissions in the tropics compared to the heavily controlled combustion processes in
\end{abstract}

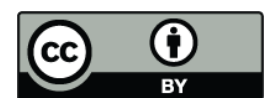

Correspondence to: J. P. Veefkind (veefkind@knmi.nl) the industrialized Northern Hemisphere. Simulations with a global chemistry transport model (GEOS-Chem) capture most of these variations, although on regional scales significant differences are found. Wintertime aerosol concentrations show strongest correlations with $\mathrm{NO}_{2}$ throughout most of the Northern Hemisphere. During summertime, AOT is often (also) correlated with enhanced HCHO concentrations, reflecting the importance of secondary organic aerosol formation in that season. We also find significant correlations between AOT and $\mathrm{HCHO}$ over biomass burning regions, the tropics in general, and over industrialized regions in southeastern Asia. The distinct summertime maximum in AOT $(0.4$ at $550 \mathrm{~nm})$ and $\mathrm{HCHO}$ over the southeastern United States strengthens existing hypotheses that local emissions of volatile organic compounds lead to the formation of secondary organic aerosols there. GEOS-Chem underestimates the AOT over the southeastern United States by a factor of 2, most likely due to too strong precipitation and too low SOA yield in the model.

\section{Introduction}

Atmospheric aerosol particles affect the Earth's climate directly by scattering and absorbing shortwave radiation, and indirectly by their effect on cloud albedo, the lifetime of clouds and precipitation patterns (Lohmann and Feichter, 2005; Yu et al., 2006). Despite a decade of scientific focus on aerosol-climate interaction, aerosols are still one of the leading uncertainties in global and regional climate change (Solomon et al., 2007). One of the most important reasons for the limited understanding of the effects of aerosols is their strong temporal and spatial variability in chemical

Published by Copernicus Publications on behalf of the European Geosciences Union. 
composition and size distribution. Important anthropogenic sources for aerosols are transportation, power plants, industries and biomass burning. Natural sources include windblown dust, sea spray, biogenic emissions, volcanoes, and biomass burning. Together, these sources form a complex chemical mixture of desert dust, sea salt, sulfates, nitrates and organic material. To describe the past and current climate and predict climate change, accurate knowledge is needed on the complex relation between the aerosol composition, the emissions of precursor gases, and primary aerosol emissions.

Detailed in situ measurements of the aerosol size and composition and their precursor gases, can be done using dedicated ground based measurements such as available at large observation sites (e.g. Stokes and Schwartz, 1994). While such measurements provide detailed information, they are limited to a few locations and sample only the aerosols close to the surface. Airborne measurements provide detailed information over larger areas, including vertical profiles, but are limited to campaigns and therefore have very limited temporal coverage. Satellite measurements have the horizontal and temporal coverage to assess the global effect of aerosols on climate, but the information on aerosols and tropospheric trace gases is limited. Dedicated satellite aerosol instruments provide the aerosol optical thickness (AOT) as well as the fine mode fraction over cloud-free areas, which can be used to distinguish the fine mode, dominated by anthropogenic sources, and the coarse mode, dominated by natural sources (Kaufman et al., 2002). Measurements in the ultraviolet can detect elevated layers of absorbing aerosols, e.g. desert dust and biomass burning plumes even over clouds and high reflecting surfaces (Dirksen et al., 2009; Herman et al., 1997).

In addition to information on aerosols, tropospheric columns of nitrogen dioxide $\left(\mathrm{NO}_{2}\right)$, formaldehyde $(\mathrm{HCHO})$ and sulfur dioxide $\left(\mathrm{SO}_{2}\right)$ can be observed from space (e.g. Boersma et al., 2007; Krotkov et al., 2006; De Smedt et al., 2008). $\mathrm{NO}_{2}$ in the troposphere is predominantly from anthropogenic sources, such as fossil fuel combustion and biomass burning. Apart from a precursor for nitrate aerosol particles, tropospheric $\mathrm{NO}_{2}$ is also a good indicator for combustion processes. The lifetime of $\mathrm{NO}_{2}$ in the lower troposphere is temperature-dependent and typically ranges from a few hours in summer to approximately a day in winter. $\mathrm{HCHO}$ is one of the most abundant hydrocarbons in the atmosphere and is an important indicator for non-methane volatile organic compounds (NMVOC) emissions that are the precursors for secondary organic aerosols (SOAs). Although $\mathrm{HCHO}$ is a primary product from biomass burning and fossil fuel combustion, the dominant global source is the photochemical oxidation of methane and non-methane hydrocarbons (De Smedt et al., 2008). A well-described biogenic source for $\mathrm{HCHO}$ are the isoprene emissions by broadleaf trees in the southeastern United States in the summer months (Chance et al., 2000; Millet et al., 2008). The lifetime of $\mathrm{HCHO}$ in the lower troposphere is of the order $1.5-4 \mathrm{~h} . \mathrm{SO}_{2}$ is the precursor gas for sulfate aerosol particles and is re- leased into the atmosphere by anthropogenic and volcanic sources. Its lifetime is of the order of 0.5 to a few days (Dickerson et al., 2007). Anthropogenic $\mathrm{SO}_{2}$ observations from space are challenging, because of the strong ozone absorption in the UV wavelengths $(310 \mathrm{~nm}-330 \mathrm{~nm})$ from which $\mathrm{SO}_{2}$ is derived (Krotkov et al., 2006, 2008; Lee et al., 2009). In addition, the $\mathrm{SO}_{2}$ concentrations in many of the developed countries have been reduced to the detection limit or below. Therefore, the use of $\mathrm{SO}_{2}$ satellite observations is limited to strongly polluted regions, like China (Krotkov et al., 2008; Witte et al., 2009), specific polluting power plants (Li et al., 2010) and smelters (Carn et al., 2007), and to volcanic eruptions (Carn et al., 2008, 2009; Krueger et al., 2009; Yang et al., 2007, 2009a, 2009b).

In this work we explore the information on aerosol composition that is contained in the combined datasets of aerosol optical thickness (AOT) from the Moderate Resolution Imaging Spectroradiometer (MODIS) (Remer et al., 2005) and $\mathrm{NO}_{2}, \mathrm{SO}_{2}$ and formaldehyde ( $\mathrm{HCHO}$ ) columns from the Ozone Monitoring Instrument (OMI) (Levelt et al., 2006). The motivation for investigating this combination is that aerosols and these trace gases share important anthropogenic and biogenic sources. Fossil fuel combustion is an important source for aerosol precursor gases, such as $\mathrm{NO}_{\mathrm{x}}, \mathrm{SO}_{\mathrm{x}}$ and NMVOCs, and for primary aerosols particles. From the precursor gases secondary nitrate, sulfate and organic aerosols are formed. Biomass burning is an important source for $\mathrm{NO}_{\mathrm{x}}$ and NMVOCs as well as primary soot and organic particles. Biogenic emissions of isoprene are a precursor for formaldehyde and SOAs. In addition, isoprene is also strongly correlated with other SOA precursors such as monoterpenes. Given the concurrent overlap of trace gases and aerosols, temporal and spatial correlation is expected between trace gases and aerosols for regions where these sources dominate the aerosol loading, provided that the lifetimes are of the same order. In general, the lifetime of aerosol particles in the lower troposphere is up to several days, whereas the lifetimes of the trace gases used in this study are generally shorter than $24 \mathrm{~h}$ in summer. Because of the difference in lifetimes, aerosols will be further transported from the source regions than the trace gases. However, because of the dayto-day variations in advection, the difference in lifetimes can be discarded as long as the data are averaged over longer periods and large regions. To reduce the impact of different lifetimes, temporal averages of at least a month and spatial averages of thousands of $\mathrm{km}^{2}$ are used in this work.

After describing the data that are used in this study, results of the spatial correlation between aerosols and $\mathrm{NO}_{2}$ are presented and compared to simulations with the global 3-D chemistry transport model (CTM) GEOS-Chem (Bey et al., 2001). We note that past studies have typically used single satellite product to constrain emissions in chemistry transport models, such as MOPITT CO, OMI NO${ }_{2}$, MISR AOT and $\mathrm{OMI} \mathrm{SO}$ for GEOS-chem (Boersma et al., 2008; Kopacz et al., 2010; Liu et al., 2004). However, given the intrinsic 
connections among each of these components in the aerosol formation processes, a combined use of two or more satellite datasets to evaluate a CTM, as we demonstrate in this study, provides a more comprehensive evaluation of model performance indicate future directions for model improvement. We show the similarities of the spatial distribution of AOT and trace gas concentrations in different regions over the globe, and the ability of GEOS-Chem simulation to capture these similarities. Finally, a case study over the southeastern United States illustrates that the spatial-temporal correlation analysis between $\mathrm{HCHO}$ and AOT can be employed as powerful tool to quantify the AOT from biogenic sources in this region.

\section{Data sets}

Aerosol data from the MODIS sensor on board the NASA EOS Aqua satellite and trace gas data from OMI on board NASA EOS Aura satellite are used. MODIS is an imager with 36 spectral channels covering the spectral range from the visible to the thermal infrared. OMI is a UV-visible spectrometer contributed by The Netherlands and Finland to the Aura mission. The Aqua and Aura satellites are both part of the A-Train and observe the same air mass within $15 \mathrm{~min}$ of each other. Satellite observations of AOT, $\mathrm{NO}_{2}, \mathrm{SO}_{2}$ and HCHO for the period 2005-2007 are used.

For MODIS the data set is obtained from the Giovanni web service (http://disc.sci.gsfc.nasa.gov/giovanni) and consists of monthly mean Collection 5 AOT from MODIS on a $1^{\circ} \times 1^{\circ}$ latitude-longitude grid. According to Remer et al. (2005), the overall accuracy of the MODIS AOT over land is estimated to be $15 \%$ with a minimum of 0.05 . However, depending on the assumptions on surface types and aerosol optical properties, the accuracy may be lower for specific regions of the world.

We use OMI $\mathrm{NO}_{2}$ data are from the DOMINO collection 3 product (Boersma et al., 2007), for which monthly averages are available on a $0.125^{\circ} \times 0.125^{\circ}$ grid from the TEMIS (http://www.temis.nl) web service. Comparisons with ground-based and in situ data suggest that the OMI tropospheric $\mathrm{NO}_{2}$ columns are biased high by $0-30 \%$, depending on the validation data set used (Hains et al., 2010; Lamsal et al., 2010).

Monthly OMI HCHO (Kurosu et al., 2008) and planetary boundary layer (PBL) $\mathrm{SO}_{2}$ data (Krotkov et al., 2006) were averaged on a $1^{\circ} \times 1^{\circ}$ grid using Level 2 Collection 3 data sets from NASA's Goddard Space Flight Center Earth Sciences (GES) Data and Information Services Center (DISC) at http://disc.sci.gsfc.nasa.gov/Aura/ data-holdings/OMI/ . The precision of the monthly averaged HCHO data product on a $1^{\circ} \times 1^{\circ}$ grid is of the order $1 \times 10^{15}$ molecules $\mathrm{cm}^{-2}$. The precision of the OMI PBL $\mathrm{SO}_{2}$ Level 2 data is $\sim 1.5$ Dobson Units (one standard deviation; $1 \mathrm{DU}=2.69 \times 10^{16}$ molecules $\mathrm{cm}^{-2}$ ) under optimal observational conditions (no clouds, near nadir viewing directions, solar zenith angle less than $60^{\circ}$ and slant column ozone less than $1500 \mathrm{DU}$ ), but is reduced to $\sim 0.5 \mathrm{DU}$ in $1^{\circ}$ by $1^{\circ}$ spatial averages (Krotkov et al., 2008). Under cloud-free conditions the bias is dominated by assumption of a fixed global air mass factor $(\mathrm{AMF}=0.36)$. A recent study (Lee et al., 2009) applying GEOS-Chem simulated $\mathrm{SO}_{2}$ and aerosol profiles suggests a seasonal average AMF of $\sim 0.5$ over China. This suggests possible $20-30 \%$ high bias. Validation against aircraft measurements over northeastern China (Dickerson et al., 2007; Krotkov et al., 2008; Xue et al., 2009) has shown that the operational OMI PBL $\mathrm{SO}_{2}$ product can distinguish between clean and polluted conditions.

The MODIS AOT retrievals can only be applied after strict cloud screening. For the OMI trace gas observations some sub-pixel cloudiness can be accounted for. For $\mathrm{NO}_{2}$ and $\mathrm{HCHO}$ only those observations have been used for which at least half of the photons originate from the cloud-free part of the ground pixel. For $\mathrm{SO}_{2}$ only scenes with a radiative cloud fraction of less than 0.2 have been included in the averages. To assess the impact of the strict MODIS cloud mask and the more relaxed OMI cloud filters on the spatial and temporal sampling we have to account for the difference in ground pixel size of the instruments. Globally $\sim 30 \%$ of the $1 \times 1 \mathrm{~km}^{2}$ MODIS observations will be cloud free and $\sim 25 \%$ of the OMI $13 \times 24 \mathrm{~km}^{2}$ observations will have a cloud fraction less than 20\% (Krijger et al., 2007). Thus the higher spatial resolution of MODIS compared to OMI compensates for the stricter cloud screening criteria applied to the AOT data, resulting in a comparable spatial and temporal sampling of the MODIS AOT and OMI trace gas data in the $1^{\circ}$ by $1^{\circ}$ spatial averages.

For all the satellite data sets monthly, seasonal and annual means were computed from the monthly means for the years 2005-2007. From these data, average values for period 2005-2007 have been computed per season and for the complete period.

From the monthly averaged data the AOT to $\mathrm{NO}_{2}$ ratio is calculated. As discussed in Sect. 3.3, this ratio can be used as indicator for regional pollution control measures. Given the above mentioned accuracies for the AOT and $\mathrm{NO}_{2}$ products and the fact that the errors in these products are not correlated, the accuracy of the AOT to $\mathrm{NO}_{2}$ ratio for regions where the concentrations are dominated by anthropogenic sources is estimated to be $20-35 \%$.

For the year 2005 a model run of the GEOS-Chem model V08-01-01 (Bey et al., 2001) was created. GEOS-Chem (http://acmg.seas.harvard.edu/geos) is a global 3-D Eulerian CTM driven by assimilated meteorological fields from the Goddard Earth Observation System (GEOS) of the NASA Global Modeling and Assimilation Office (GMAO). It includes state-of-science representations of the tropospheric chemistry for trace gases (such as $\mathrm{CO}, \mathrm{O}_{3}, \mathrm{NO}_{\mathrm{x}}, \mathrm{SO}_{\mathrm{x}}$, $\mathrm{CH}_{4}, \mathrm{HCHO}$ and other organic gases) and for aerosols (such 
as sulfate, nitrate, ammonium, organic aerosol, black carbon, soil dust, and sea salt). The tropospheric chemical mechanism comprises SMVGEARII solver of Jacobson (1995), and includes the coupling between gas-phase chemistry and heterogeneous reactions, the inorganic aerosol thermodynamics, and oxidative aging of carbonaceous aerosols (Park et al., 2004).

Aerosol simulations are coupled to gas-phase chemistry through nitrate and ammonium partitioning, sulfur chemistry, secondary OA (SOA) formation, and uptake of acidic gases by sea salt and dust. Wet scavenging includes removal in convective updrafts as well as first-order rainout and washout, and is regularly tested using ${ }^{210} \mathrm{~Pb}$ and ${ }^{7} \mathrm{Be}$ benchmark simulations (Liu et al., 2001). The standard GEOSChem model prescribes the RH-dependent size distributions and refractive indices for the different aerosol components in order to calculate optical properties under the assumption of external mixing (Martin et al., 2003). The calculation used the GADS optical properties data base (Koepke et al., 1997), with updates by Wang et al. (2008), Drury et al. (2010) and Wang et al. (2010).

The GEOS-Chem dust simulation uses the source function from Fairlie et al. (2007), which blends the dust mobilization and entrainment scheme from the DEAD model (Zender et al., 2003) with the source function from the GOCART model (Ginoux et al., 2001) (Chin et al., 2004). Dust aerosol emission and transport is resolved into four size bins (Ginoux et al., 2004) with radii 0.1-1. 1-1.8, 1.8-3.0, and $3.0-6.0 \mu \mathrm{m}$. Sulfur anthropogenic emissions are from an ensemble of national inventories as described by van Donkelaar et al. (2008). Fuel organic aerosol emissions are from Bond et al. (2007), open biomass burning emissions for individual years are from the weekly MODIS-based GFED3 inventory (Giglio et al., 2010), and biogenic emissions of isoprene and terpenes are from MEGAN (Guenther et al., 2006). Instantaneous yields of $10 \%$ SOA for terpenes and $2 \%$ for isoprene is used in GEOS-Chem (Heald et al., 2006). Ammonia emission is from Global Emissions Inventory Activity (GEIA) data for NH3 (Bouwman et al., 1997), with updates in United States by Henze et al. (2009) through inverse modelling using ground-based IMPROVE data as constraints.

For this study, the output of the model includes $\mathrm{NO}_{2}$ and $\mathrm{HCHO}$, as well as AOT for the various aerosol species in the model. These species include sulfates, nitrates, dust, sea salt and SOA. The output of the GEOS-Chem model is sampled at $13: 30 \mathrm{~h}$ local time, which is the approximate local time of the A-Train satellite overpass. From the daily values monthly means are constructed on a $2^{\circ}$ by $2.5^{\circ}$ latitude longitude grid that are interpolated to a $1^{\circ} \times 1^{\circ}$ grid to match the satellite datasets. Similar to the satellite data, seasonal and annual means for the model data are constructed.

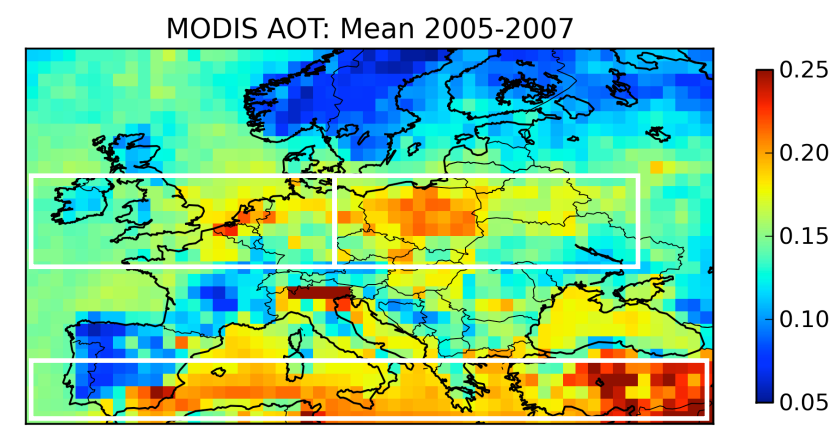

OMI Tropospheric NO2: Mean 2005-2007

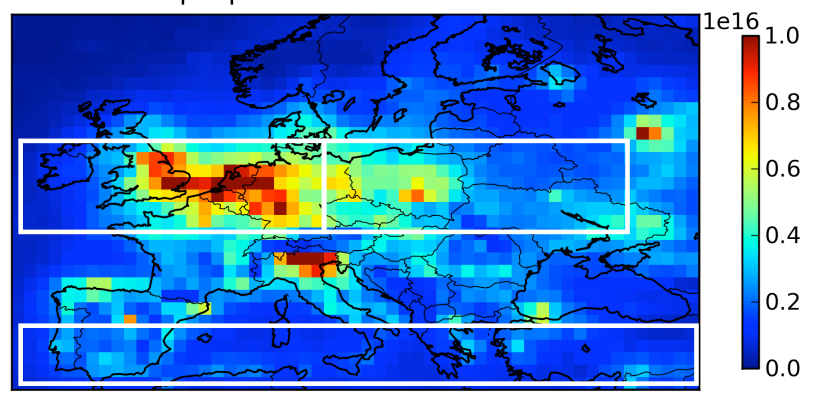

Fig. 1. Bottom panel: OMI tropospheric $\mathrm{NO}_{2}$ in molecules $\mathrm{cm}^{-2}$. Top panel: MODIS AOT at $550 \mathrm{~nm}$. Both figures are averages over the period 2005-2007 and are on a $1^{\circ} \times 1^{\circ}$ degree latitude longitude grid. Three areas are indicated in these images: an area over western Europe, an area over eastern Europe and an area over the Mediterranean basin.

\section{Results and discussion}

\subsection{Case study over Europe}

As a first example of the spatial correlation between aerosols and trace gases from common emission sources, Fig. 1 shows annual average tropospheric $\mathrm{NO}_{2}$ columns and AOT over Europe. The $\mathrm{NO}_{2}$ columns show maxima over densely populated and heavily industrialized regions such as the German Ruhr area, the Rotterdam-Antwerp region in The Netherlands and Belgium and the Po Valley in Italy. Over these regions the AOT is also high, but we find additional high values over Poland and the Mediterranean basin. Furthermore, the figure suggests strong spatial correlation between AOT and $\mathrm{NO}_{2}$ for large cities in eastern Europe such as Moscow and Kiev.

Figure 2 shows scatter plots between the AOT and tropospheric $\mathrm{NO}_{2}$ for the three areas indicated in Fig. 1. Each point in the plots represents a $1^{\circ} \times 1^{\circ}$ grid box in one of the areas indicated in Fig. 1. Over both western and eastern Europe the AOT and tropospheric $\mathrm{NO}_{2}$ show significant correlation, with a spatial correlation coefficient of 0.8 and 0.6, respectively. Western Europe is characterized by high values of tropospheric $\mathrm{NO}_{2}$ and AOT between 0.1 and 0.25 . In eastern Europe the AOT is in the same range, but $\mathrm{NO}_{2}$ concentrations are significantly lower. This results in a higher 

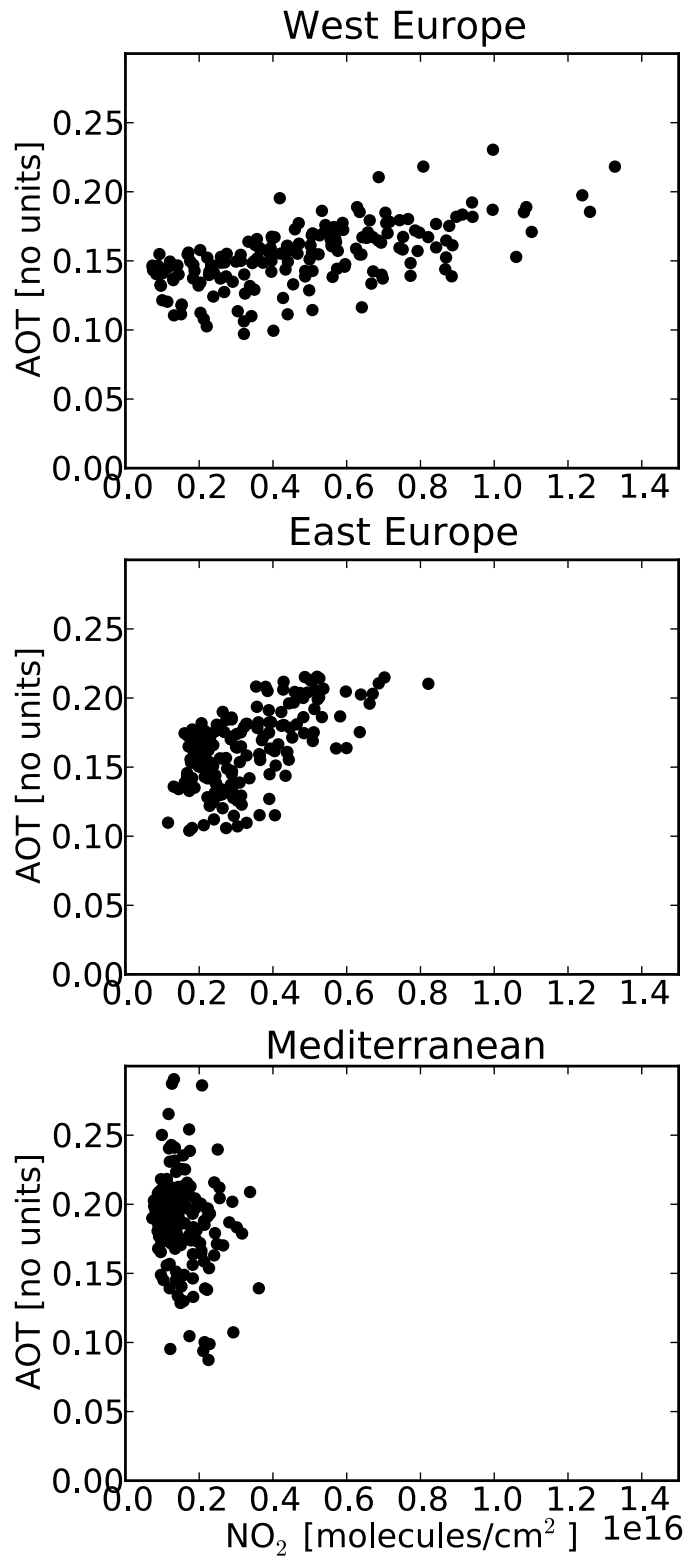

Fig. 2. Scatter plots between the AOT and $\mathrm{NO}_{2}$ for the three areas indicated in Fig. 1: western Europe (top panel), eastern Europe (middle panel) and Mediterranean basin (bottom panel). The AOT and tropospheric $\mathrm{NO}_{2}$ are averages over the period 20052007.

slope between AOT and tropospheric $\mathrm{NO}_{2}$ for eastern $\mathrm{Eu}-$ rope as compared to western Europe. Assuming a linear relationship between surface $\mathrm{NO}_{\mathrm{x}}$ emissions and tropospheric $\mathrm{NO}_{2}$ columns (Martin et al., 2006) and that aerosols and $\mathrm{NO}_{\mathrm{x}}$ originate from the same combustion sources, a higher slope indicates fewer molecules of $\mathrm{NO}_{\mathrm{x}}$ are formed per unit AOT. This presumably reflects higher $\mathrm{SO}_{2} / \mathrm{NO}_{\mathrm{x}}$ emission ratios over eastern Europe than over western Europe, leading to more sulfate-rich aerosols over eastern Europe. Indeed, the
EDGAR emission inventory (EDGAR, 2005) shows that the $\mathrm{SO}_{\mathrm{x}} / \mathrm{NO}_{\mathrm{x}}$ ratio is approximately two times higher over the eastern Europe, as compared to western Europe. Regional differences in slope thus provide indirect information on the aerosol composition and underlying emissions.

The Mediterranean area is used a control region, where the Saharan dust is the dominating contribution to the AOT. As expected, Fig. 2 indicates no spatial correlation between AOT and tropospheric $\mathrm{NO}_{2}$ over the Mediterranean area.

\subsection{Spatial correlation over industrial and biomass burning regions}

In this section the spatial correlation between AOT and $\mathrm{NO}_{2}$ is explored for four selected regions in Europe, China, the United States and Africa listed in Table 1. We analyse seasonal differences in the AOT to $\mathrm{NO}_{2}$ correlation and compare the results with model simulations. The selected area over the west coast of Africa is dominated by biomass burning; the other three areas are dominated by fossil fuel emissions. Figure 3 shows scatter plots between AOT and tropospheric $\mathrm{NO}_{2}$ for the summer and winter season. The left panels in this figure show satellite observations and the right panels the GEOS-Chem simulations.

In all of the satellite observations presented in Fig. 3, except for the winter months over the eastern United States and West Europe, spatial correlation is observed between AOT and tropospheric $\mathrm{NO}_{2}$, suggesting that the sources that emit $\mathrm{NO}_{\mathrm{x}}$ also drive the AOT. What is striking in Fig. 3 is the difference in the slopes between the different regions. In the previous section, we proposed that the difference in slope for regions with comparable photochemical regimes may be caused by regional differences in the nature of the combustion process, e.g. type of fossil fuel, use of clean burning technologies, etc. The comparable low slopes for the areas over western Europe and the east coast of the United States, where strong emissions regulations apply, support this idea. For the biomass burning area over the west coast of Africa, where there are no measures to reduce emissions of various trace gases and primary aerosols, it is plausible that more primary and/or secondary aerosols are produced compared to the case of controlled fossil fuel combustion in the industrialized regions. This is a qualitative explanation for the large slope between AOT and $\mathrm{NO}_{2}$ in these biomass burning regions. For the Chongqing-Chengdu region in China, the absence of strict regulations on $\mathrm{SO}_{2}$ emissions and other pollutants can also explain the high slope between AOT and $\mathrm{NO}_{2}$. However, other effects that influence the formation and sinks of aerosols, such as high relative humidity, high temperatures and the trapping of the aerosols in a basin may contribute to the large slope over Chongqing as well.

As shown in the right panels of Fig. 3, the GEOS-Chem simulations reproduce the observed AOT- $\mathrm{NO}_{2}$ slopes for the studied areas, except for the European case. For the east coast of the United States the AOT- $\mathrm{NO}_{2}$ is much larger in 

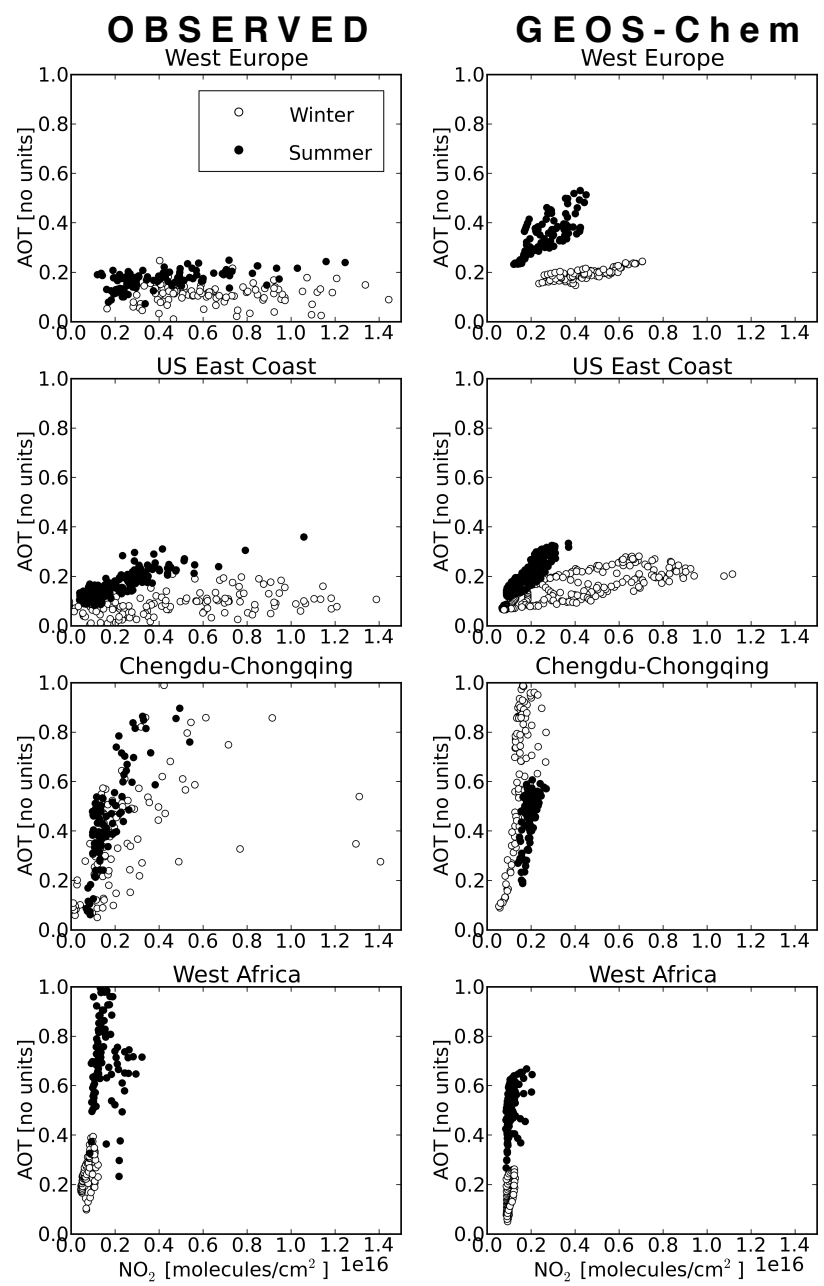

Fig. 3. Scatter plots between AOT and tropospheric $\mathrm{NO}_{2}$ for four areas: West Europe, US East Coast, West coast of Africa and the area around Chonqing-Chendu in China. The plots in the left column show observations for the period 2005-2007, the right column shows GEOS-Chem simulations for 2005. Open symbols show the winter months (December-January-February) and filled symbols the summer months (June-July-August).

Table 1. List of the areas used in Fig. 3.

\begin{tabular}{lrr}
\hline Area & Latitude Range & Longitude Range \\
\hline West Europe & $45^{\circ} \mathrm{N}-55^{\circ} \mathrm{N}$ & $2.5^{\circ} \mathrm{W}-7.5^{\circ} \mathrm{E}$ \\
US East Coast & $40^{\circ} \mathrm{N}-50^{\circ} \mathrm{N}$ & $70^{\circ} \mathrm{W}-90^{\circ} \mathrm{W}$ \\
Africa West Coast & $3^{\circ} \mathrm{S}-13^{\circ} \mathrm{S}$ & $5^{\circ} \mathrm{E}-15^{\circ} \mathrm{E}$ \\
China, Chengdu -Chongqing & $25^{\circ} \mathrm{N}-35^{\circ} \mathrm{N}$ & $102^{\circ} \mathrm{E}-112^{\circ} \mathrm{E}$ \\
\hline
\end{tabular}

the summertime, which could be explained by shorter lifetimes of $\mathrm{NO}_{2}$ in the summer and higher summer AOT. However, such an effect is not observed over Europe nor over the Chongqing-Chengdu region. Another explanation for the increased AOT-NO $\mathrm{N}_{2}$ for the east coast of the United States in summer could be the seasonal variations in biogenic emissions causing increased levels of SOA in the summer. We will discuss this in more detail in Sect. 3.5. For the area over western Europe the model overpredicts the AOT, while under predicting the $\mathrm{NO}_{2}$ concentration, which leads to much larger AOT- $\mathrm{NO}_{2}$ slopes as compared to the observations. We attribute too high AOT-NO $\mathrm{N}_{2}$ ratios simulated by GEOSChem mainly to overestimations of the AOT by GEOS-Chem $(2 \times 3$ times higher than MODIS AOT). Furthermore, the model simulations show a much stronger seasonal variation. For the biomass burning region in Africa the observed strong variation in the AOT is well-captured by the model. Both the satellite observations and the model simulations indicate no significant seasonal variations in the AOT- $\mathrm{NO}_{2}$ slope in this region.

Four selected regions show significant spatial correlation between $\mathrm{AOT}$ and $\mathrm{NO}_{2}$ for different conditions, but the slope between AOT and $\mathrm{NO}_{2}$ varies strongly between the selected areas. The GEOS-Chem reproduces these findings, providing confidence in our understanding of aerosol sources, formation mechanism and sinks over these areas. The slope between AOT and $\mathrm{NO}_{2}$ maybe used as a first order indicator for the amount of secondary and primary aerosols produced by the combustion process. We therefore propose to use the AOT to $\mathrm{NO}_{\mathrm{x}}$ ratio in the source regions as an regional pollution control indicator: low AOT to $\mathrm{NO}_{2}$ values of this ratio indicate controlled efficient combustion and high values are indicative of highly polluting, uncontrolled combustion processes.

\subsection{Global AOT to $\mathrm{NO}_{2}$ ratio}

In this section we analyse the AOT to $\mathrm{NO}_{2}$ ratio in polluted regions and biomass burning regions globally. In this analysis, $\mathrm{NO}_{2}$ is primarily used as a tracer for combustion processes. In regions without common sources, e.g. for desert dust regions and remote oceans where sea salt dominates the aerosols loadings, the AOT to $\mathrm{NO}_{2}$ ratio is very high. This can for instance be seen in the plot for the Mediterranean area in Fig. 2. Thus, to use the AOT to $\mathrm{NO}_{2}$ ratio as indicator for the aerosol source strength of pollution processes, we limit the analyses to areas dominated by fossil fuel combustion or biomass burning. Because tropospheric $\mathrm{NO}_{2}$ is a good indicator of combustion, we require tropospheric columns in excess of $7 \times 10^{14}$ molecules $\mathrm{cm}^{-2}$. The top panel of Fig. 4 shows the satellite observations of the AOT to $\mathrm{NO}_{2}$ ratio for regions exceeding the threshold. We see large areas with consistent AOT to $\mathrm{NO}_{2}$ ratios. The highest values in the observed AOT to $\mathrm{NO}_{2}$ ratio are found over the major biomass burning regions in Africa and South America, whereas the lowest values are found over the United States and western Europe, reflecting the gradient in pollution control between these regions. Note that in Fig. 4 a logarithmic colour scale is used. Thus, the AOT to $\mathrm{NO}_{2}$ ratio for the biomass burning regions is a factor of 100 larger than for the industrial 
AOT: $\mathrm{NO}_{2}$ Ratio OBSERVED

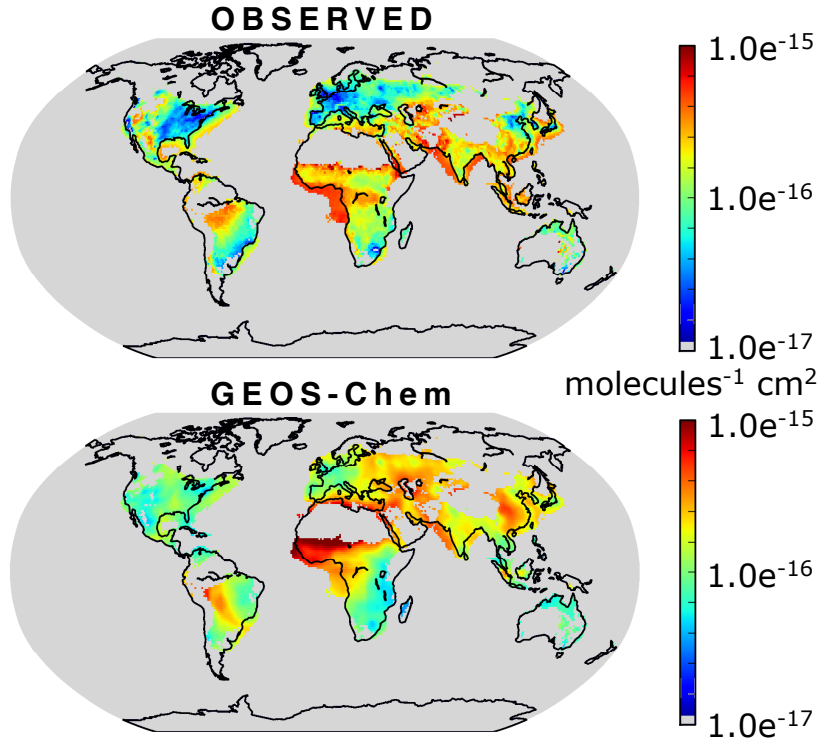

Fig. 4. Top panel: observed $\mathrm{AOT}$ to $\mathrm{NO}_{2}$ ratio for regions where tropospheric $\mathrm{NO}_{2}$ exceeds $7 \times 10^{14}$ molecules $\mathrm{cm}^{-2}$. Bottom panel: modelled AOT to $\mathrm{NO}_{2}$ ratio for the same regions as the observations. Note that a logarithmic colour scale is used.

regions in the western world. The values over India are also high, although not as high as over the biomass burning regions. These high values are consistent with the widespread inefficient burning of biofuels in this region. Over China the values for the industrialized northern region are much smaller than over the south of China. The bottom panel of Fig. 4 shows the AOT to $\mathrm{NO}_{2}$ ratio simulated by GEOSChem. Overall similar patterns are observed with the highest values for the biomass burning regions and the lowest values over the United States and Europe. However, some interesting differences are found between the observations and the model simulation. Overall in industrial regions the AOT to $\mathrm{NO}_{2}$ ratio is significantly higher in the model simulations compared to the satellite observations. Over the west of the United States much larger values are found in the satellite observations compared to the model, which is caused by a known overestimates of the MODIS AOT in this region (Drury et al., 2008; Levy et al., 2010). Also, too low values of the AOT-NO $\mathrm{NO}_{2}$ ratio are found over Indonesia by the model as compared to the observations, which can possibly explained by an overestimation of lighting $\mathrm{NO}_{\mathrm{x}}$ in the model over this region, leading to overestimated $\mathrm{NO}_{2}$ columns. Another difference in the AOT to $\mathrm{NO}_{2}$ ratios are the biomass burning regions in Africa and South America that are less pronounced and less widespread in the simulations as compared to the observations.

\subsection{Spatial correlation between $\mathrm{AOT}, \mathrm{NO}_{2}, \mathrm{HCHO}$ and $\mathrm{SO}_{2}$}

Figure 5 shows maps of AOT and columns of tropospheric $\mathrm{NO}_{2}, \mathrm{SO}_{2}$ and $\mathrm{HCHO}$ over China. Although each of the trace gas fields is spatially correlated with the AOT field and one another, they all show their own specific features. In the northeast of China the concentrations of $\mathrm{NO}_{2}, \mathrm{SO}_{2}, \mathrm{HCHO}$ as well as the AOT are high and the spatial patterns show good correlation. For the region of the cities Chongqing and Chendu in central China, the AOT, $\mathrm{HCHO}$ and $\mathrm{SO}_{2}$ are high, however $\mathrm{NO}_{2}$ is much lower compared to the industrialized northeast of China. This difference indicates that the sources controlling the aerosol composition differ between Chongqing-Chendu and northeastern China. Over central and southern China, away from the main industrial regions, the observed AOT is significant with values of the order 0.40.6 . In these regions the AOT shows mostly correlation with the enhanced $\mathrm{HCHO}$ columns, while $\mathrm{NO}_{2}$ and $\mathrm{SO}_{2}$ concentrations are low.

Although $\mathrm{HCHO}$ is an indicator for VOC emissions, its relation with SOA is only indirect. We hypothesize that the correlation between $\mathrm{HCHO}$ and AOT points to SOA formation being important in central and southern China. Whereas $\mathrm{NO}_{2}$ and $\mathrm{SO}_{2}$ are predominantly produced by the industrial sources, $\mathrm{HCHO}$ is also produced by biogenic sources. In addition, whereas the lifetime of HCHO maybe short, the complex chemistry from which it is formed may take more time and therefore the $\mathrm{HCHO}$ concentrations may be higher downwind of the source regions and correlate better with the longer-lived aerosol particles.

Global spatial correlation between AOT and $\mathrm{SO}_{2}$ and $\mathrm{HCHO}$ is shown in Fig. 6. This figure shows regions where the spatial correlation between AOT and $\mathrm{NO}_{2}$ and/or HCHO in average fields for the period 20052007 shows a correlation of better than $50 \%$. Before computing the correlation, data with tropospheric $\mathrm{NO}_{2}$ and HCHO columns below $7 \times 10^{14}$ molecules $\mathrm{cm}^{-2}$ and $7.0 \times 10^{15}$ molecules $\mathrm{cm}^{-2}$, respectively, were excluded. In these excluded regions the AOT is predominantly from natural sources (sea salt or desert dust) so no correlation with $\mathrm{NO}_{2}$ or $\mathrm{HCHO}$ is expected. The correlations are not computed for $\mathrm{SO}_{2}$ because in many regions of the world $\mathrm{SO}_{2}$ data are below the detection limit for satellite observations. Figure 6 shows that the regions with spatial correlation between AOT and the trace gases are the biomass burning regions in South America and Africa, and industrial regions in Europe, the eastern United States and southeast Asia. The significant spatial correlation in these regions indicates that the aerosol particles are formed from the same sources that also produce $\mathrm{NO}_{2}$ and $\mathrm{HCHO}$. In Europe and the United States the correlation is mostly with $\mathrm{NO}_{2}$, in the other regions the correlation with $\mathrm{HCHO}$ is also important. Especially in the tropical forest regions in South America and Africa the correlation is often only with $\mathrm{HCHO}$ and not with $\mathrm{NO}_{2}$. As for the situation 

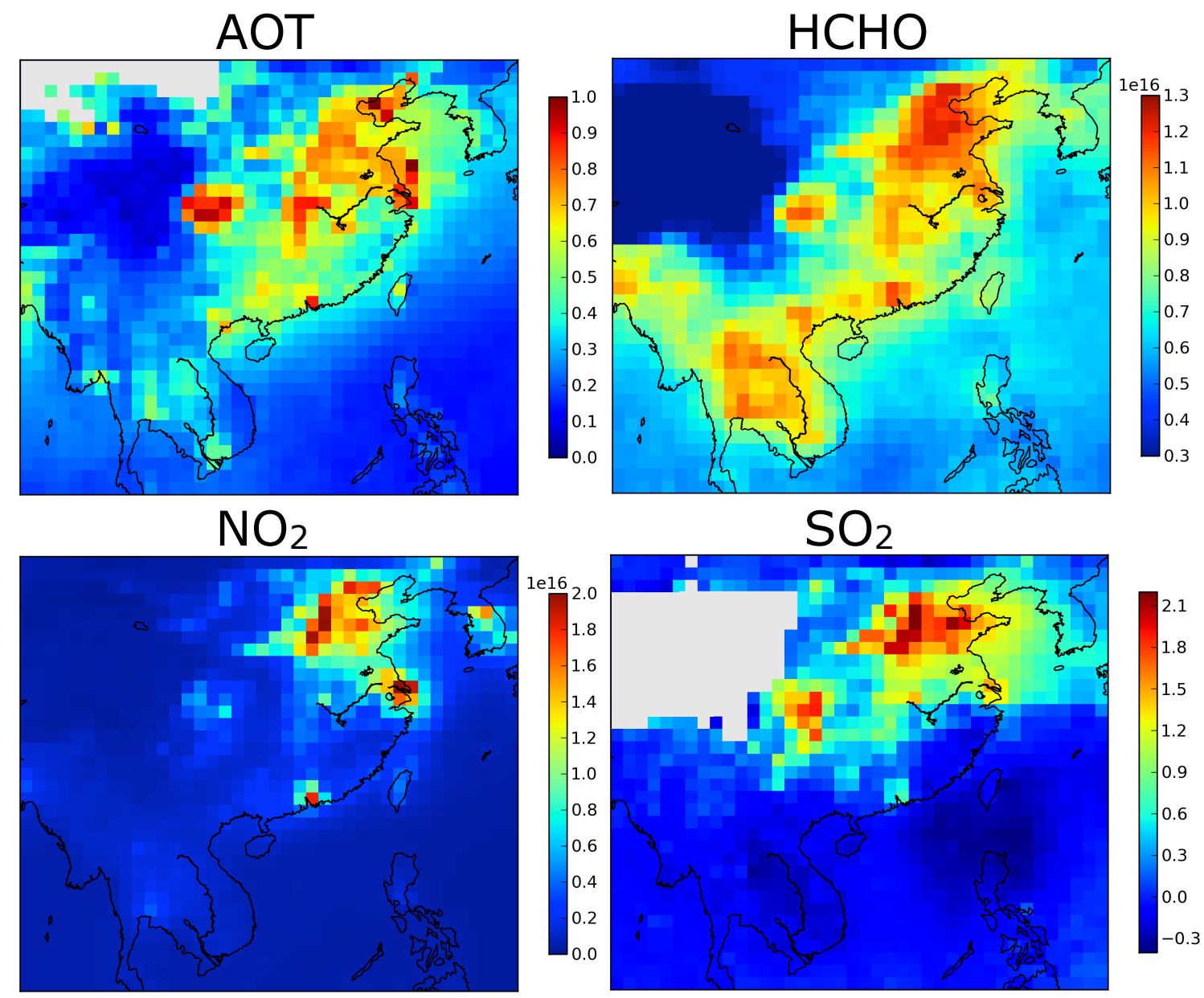

Fig. 5. Maps of mean values for the period 2005-2007 over China of AOT (upper left panel), HCHO in molecules $\mathrm{cm}^{-2}$ (upper right panel), $\mathrm{NO}_{2}$ in molecules $\mathrm{cm}^{-2}$ (lower left panel) and $\mathrm{SO}_{2}$ in DU (lower right panel).

over China, this may point to the importance of SOA in these regions, but also the difference in lifetime between $\mathrm{NO}_{2}$ and HCHO may play a role.

\subsection{SOA from biogenic sources in southeastern United States}

Here we further investigate correlations between $\mathrm{HCHO}$ and AOT over the southeastern United States. This region shows a distinct summer maximum in formaldehyde due to temperature driven biogenic emissions (De Smedt et al., 2008; Palmer et al., 2001). Figure 7 shows the AOT and anomalies for AOT, $\mathrm{NO}_{2}$ and $\mathrm{HCHO}$ over the United States for the summer months (June, July and August) over the years 2005-2007. The anomaly is computed as the seasonal mean minus the annual mean. The figure shows that the spatial distributions of the AOT and HCHO anomalies exhibit a very similar pattern over the southeastern United States. Whereas the AOT and $\mathrm{HCHO}$ both show a positive anomaly, $\mathrm{NO}_{2}$ shows a negative anomaly over this region and the spatial pattern for $\mathrm{NO}_{2}$ is also different. The negative $\mathrm{NO}_{2}$ anomaly is mostly due to the shorter lifetime of $\mathrm{NO}_{2}$ in the summer. Besides the strong spatial correlation, there is also a strong temporal correlation between satellite-observed $\mathrm{HCHO}$ and AOT $(r>0.9)$, as shown in Fig. 8. The AERONET station in Walker Branch $\left(36.0^{\circ} \mathrm{N}, 84.3^{\circ} \mathrm{W}\right)$ confirms the timing and magnitude of the summer maximum in the MODIS AOT data. Over the southeastern United States the magnitude of the JJA anomaly is of the order 0.2 AOT and $1 \times 10^{16}$ molecules $\mathrm{cm}^{-2} \mathrm{HCHO}$. The summer maximum in AOT is not reproduced by the GEOS-Chem, which shows a maximum in the spring and underestimates the AOT in summer by more than 0.2 . This large underestimate possibly is partly due to the overestimate of precipitation in GEOS4 over the southeastern United Stats in summer (Wang et al., 2009), and partially due to the underestimation of SOA yield. The only significant aerosol component in the GEOS-Chem which shows a maximum in the summer is SOA, however the AOT for this component is a factor 50-100 too small to explain the magnitude in AOT observed by MODIS and 

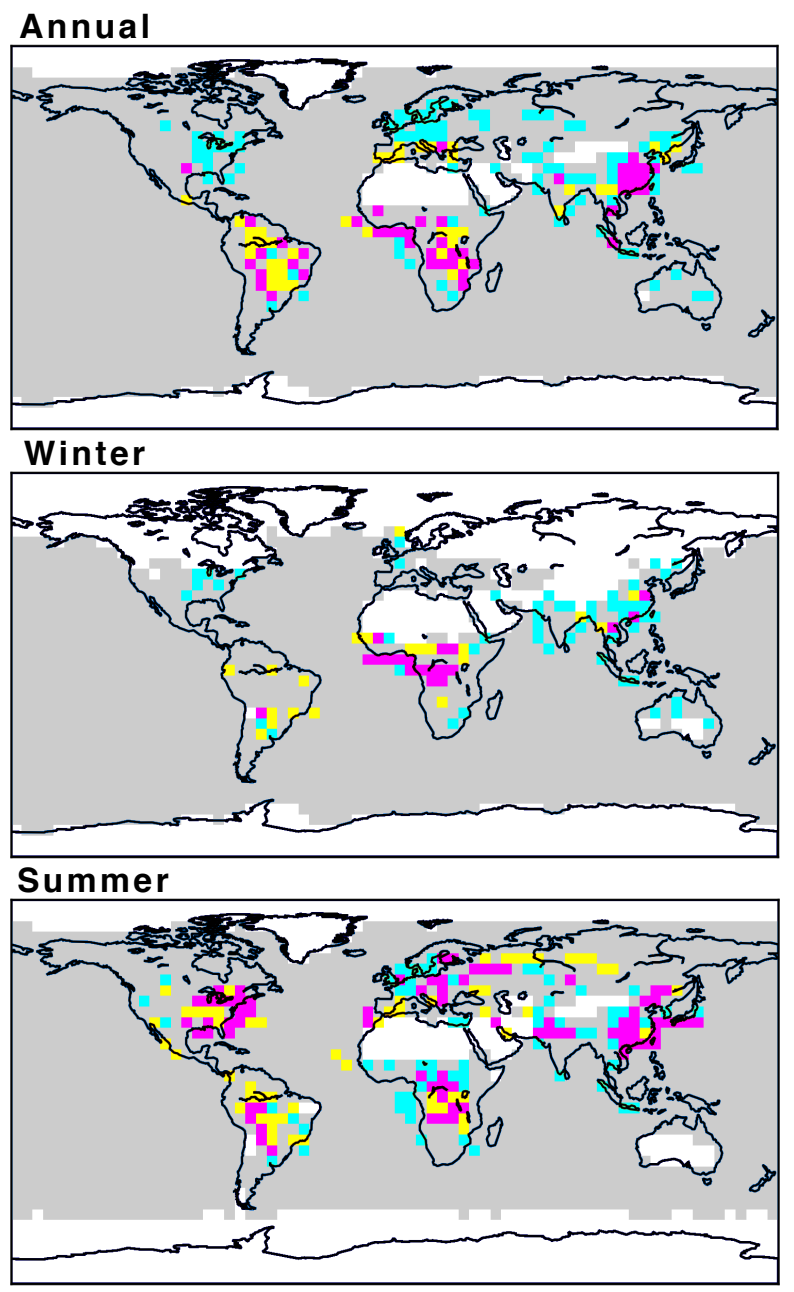

Spatial Correlation $>\mathbf{5 0} \%$ between:

$\square$ AOT and $\mathrm{NO}_{2} \square$ AOT and $\mathrm{HCHO} \square$ AOT and $\mathrm{NO}_{2}$, and $\mathrm{AOT}$ and $\mathrm{HCHO}$

Fig. 6. Spatial correlation between $\mathrm{AOT}$ and $\mathrm{NO}_{2}$ and $\mathrm{HCHO}$ for $5 \times 5^{\circ}$ grid boxes for the period 2005-2007. The colours indicate grid boxes where the spatial correlation between AOT and $\mathrm{NO}_{2}$ and/or AOT and HCHO exceeds 50\%. Grey is used for which the correlation was below $50 \%$, or either $\mathrm{NO}_{2}$ was below a threshold of $7 \times 10^{14}$ molecules $\mathrm{cm}^{-2}$ or $\mathrm{HCHO}$ was below a threshold of $7 \times 10^{15}$ molecules $\mathrm{cm}^{-2}$.

AERONET. The summertime maximum in AOT over the southeastern United States has been described in Goldstein et al. (2009), who attributed it to SOA formation. Here we report on the direct strong correlation between AOT and $\mathrm{HCHO}$ both spatially and temporally as seen from space. Although the southeastern United States is a very clear example of biogenic SOA formation, this case is not unique. In other regions of the world the seasonal signal of the SOA aerosols is often obscured by seasonal biomass burning or desert dust events and cannot be clearly identified from the satellite data alone. However, the magnitude of the AOT anomaly over the southeastern United States in summer clearly indicates its importance for the regional climate.

\section{Conclusions}

We have used the spatial and temporal correlations between concurrent satellite observations of aerosol optical thickness (AOT) from MODIS and tropospheric columns of $\mathrm{NO}_{2}$, $\mathrm{HCHO}$, and $\mathrm{SO}_{2}$ from OMI to infer information on the composition of aerosol particles. When averaging over large regions and over longer periods, we find significant correlation between MODIS AOT and OMI trace gas columns for various regions in the world. The satellite observations show low AOT to $\mathrm{NO}_{2}$ ratios over the eastern United States and western Europe, and high AOT to $\mathrm{NO}_{2}$ ratios over comparably industrialized regions in eastern Europe and China. Emission databases and $\mathrm{OMI} \mathrm{SO}_{2}$ observations over these regions are suggestive of much stronger sulphur contributions to aerosol formation than over the well-regulated areas of the eastern United States and western Europe. We propose that satelliteinferred AOT to $\mathrm{NO}_{2}$ ratios for regions with comparable photochemical regimes can be used as indicators for the relative regional pollution control of combustion processes.

To interpret the satellite observations on the global scale, we have used a global 3-D chemistry transport model (GEOS-Chem). This model includes relevant emissions of trace gases and particles, tropospheric chemistry, and aerosol formation processes. The GEOS-Chem simulations generally capture the observed AOT to $\mathrm{NO}_{2}$ ratios for different regions around the world, but over Europe, summertime GEOS-Chem AOT is too high by a factor of 2, and over the southeastern United States it is too low by a factor of 2. Both observations and GEOS-Chem indicate that AOT to $\mathrm{NO}_{2}$ ratios are a factor of 100 larger over biomass burning regions than over the industrialized regions, although on regional scales significant differences are found.

Wintertime aerosol concentrations show strongest correlations with $\mathrm{NO}_{2}$ throughout most of the Northern Hemisphere. During summertime, AOT is often also correlated with enhanced $\mathrm{HCHO}$ concentrations, reflecting the importance of secondary organic aerosol fomation in that season. We also find significant correlations between AOT and $\mathrm{HCHO}$ over biomass burning regions, the tropics in general, and over industrialized regions in southeastern Asia. Over the southeastern United States, we observe distinct summertime maxima in AOT and $\mathrm{HCHO}$, and these can be attributed to biogenic emissions of volatile organic compounds leading to the formation of formaldehyde and secondary organic aerosols. Comparison of simulated vs. observed AOT indicates that GEOS-Chem underestimates AOT over the southeastern United States, most likely caused by too strong precipitation (GEOS-4) and too low SOA-yield in the model.

Given the complexity of secondary organic aerosol formation, and the importance of SOAs in the global climate, future model development should focus on better describing these processes. Analysis of concurrent aerosol and trace gas observations, and comparison with global chemistry transport 

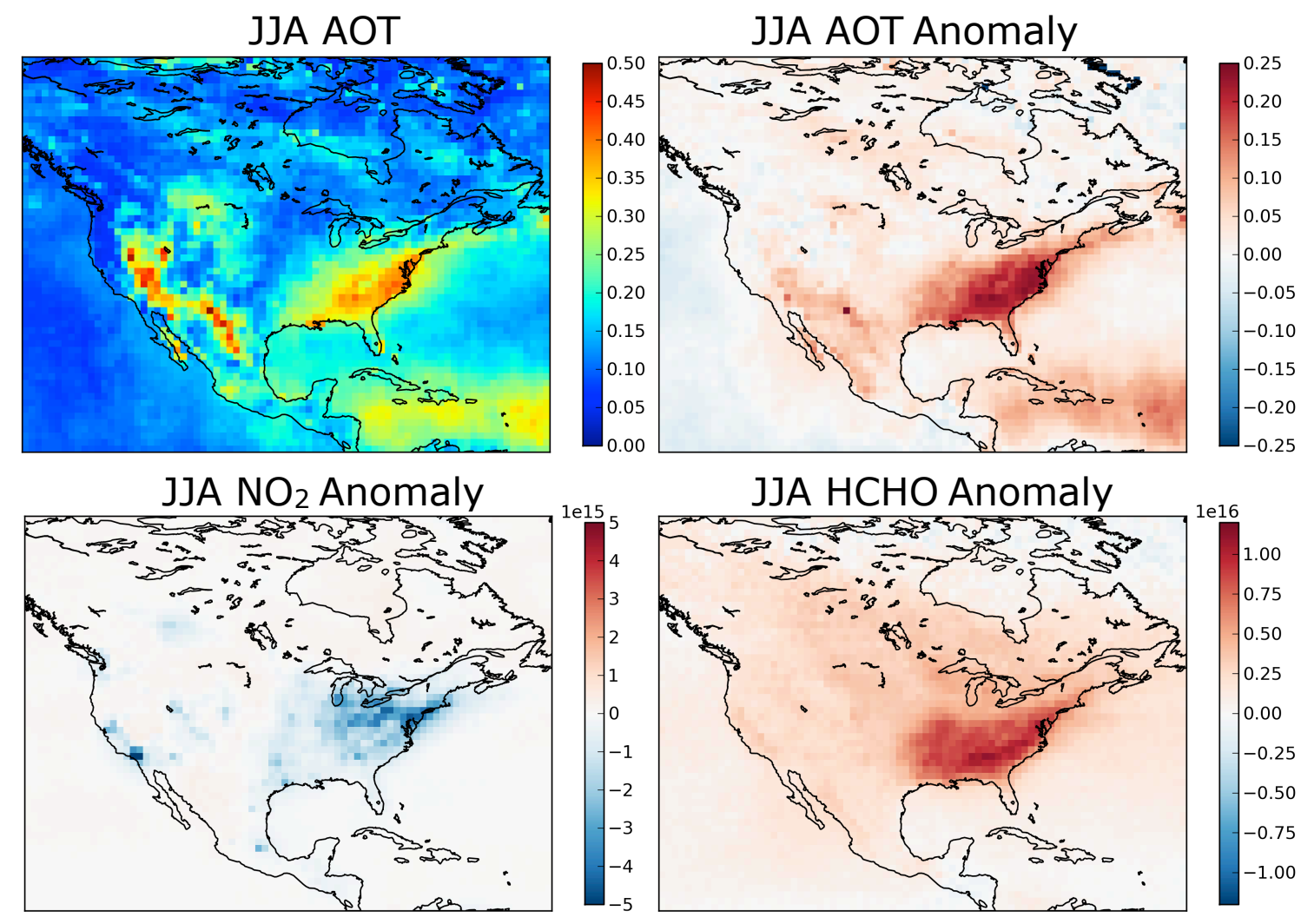

Fig. 7. Aerosol and trace gas anomaly for the summer months (June-July-August, JJA) over the United States. Top left panel: mean JJA AOT for the period 2005-2007. Top right panel: JJA AOT anomaly (summer months minus annual average) for the same period. Bottom left panel: JJA $\mathrm{NO}_{2}$ anomaly. Bottom right panel: JJA HCHO anomaly.
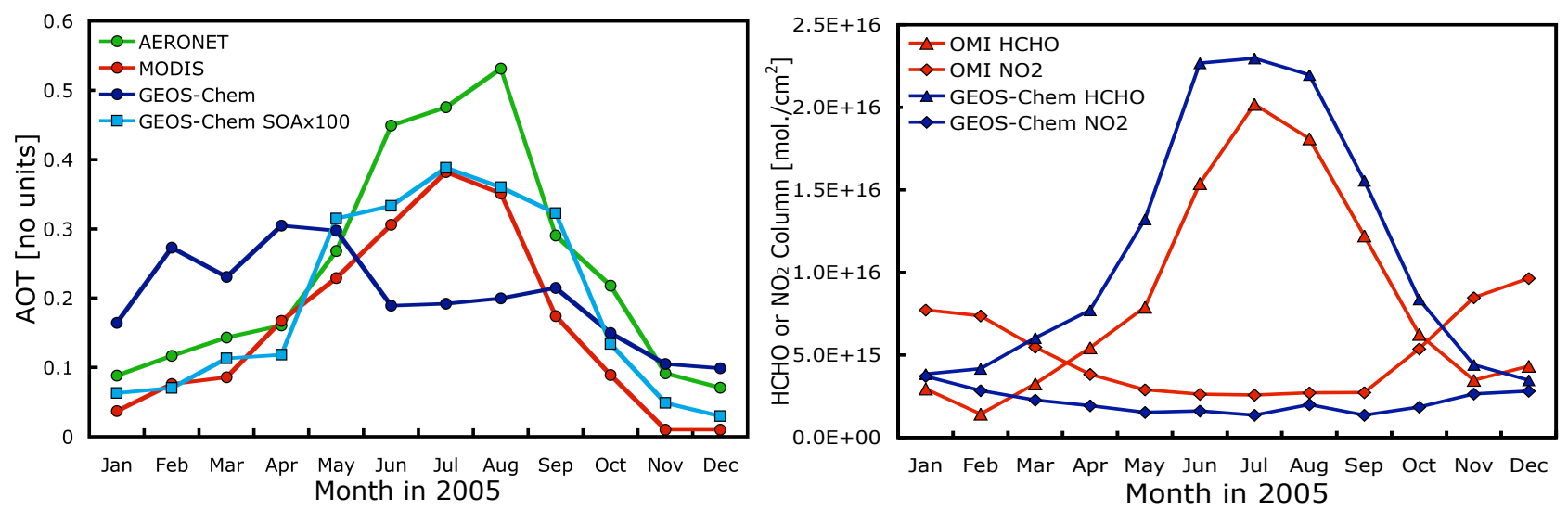

Fig. 8. Seasonal variations in aerosols and trace gases for the grid box centered at $33.5^{\circ} \mathrm{N}, 85.5^{\circ} \mathrm{W}$. Left panel shows the AOT from satellite (MODIS) and ground-based (AERONET) remote sensing, as well as model simulations with GEOS-Chem. Also, the GEOS-Chem AOT for the SOA component multiplied with a factor of 100 is shown. The right panel shows the $\mathrm{HCHO}$ and $\mathrm{NO}_{2}$ troposheric columns from satellite observations (OMI) and GEOS-Chem simulations. 
models, provides a rich source of information for understanding aerosol processes and simulations, in particular with respect to secondary aerosols.

Acknowledgements. This work is funded by the Netherlands Space Office (NSO). Jun Wang's participation to this work is supported by the NASA Earth Science New Investigator program. The OMI instrument was contributed by the Netherlands (NSO/KNMI) and Finland (TEKES/FMI) to the NASA EOS-Aura mission. We also acknowledge the MODIS and AERONET mission scientists and associated NASA personnel for the production of the data used in this research effort.

Edited by: M. van Roozendael

\section{References}

Bey, I., Jacob, D. J., Yantosca, R. M., Logan, J. A., Field, B. D., Fiore, A. M., Li, Q., Liu, H. Y., Mickley, L. J., and Schultz, M. G.: Global modeling of tropospheric chemistry with assimilated meteorology- Model description and evaluation, J. Geophys. Res., 106, 23073-23095, doi:10.1029/2001JD000807, 2001.

Boersma, K. F., Eskes, H. J., Veefkind, J. P., Brinksma, E. J., van der A, R. J., Sneep, M., van den Oord, G. H. J., Levelt, P. F., Stammes, P., Gleason, J. F., and Bucsela, E. J.: Near-real time retrieval of tropospheric $\mathrm{NO}_{2}$ from OMI, Atmos. Chem. Phys., 7, 2103-2118, doi:10.5194/acp-7-2103-2007, 2007.

Boersma, K. F., Jacob, D. J., Bucsela, E. J., Perring, A. E., Dirksen, R., Van der A, R. J., Yantosca, R. M., Park, R. J., Wenig, M. O., Bertram, T. H., and Cohen, R. C.: Validation of OMI tropospheric $\mathrm{NO}_{2}$ observations during INTEX-B and application to constrain $\mathrm{NO}_{\mathrm{x}}$ emissions over the eastern United States and Mexico, Atmos. Environ., 42, 4480-4497, 2008.

Bond, T. C., Bhardwaj, E., Dong, R., Jogani, R., Jung, S., Roden, C., Streets, D. G., and Trautmann, N. M.: Historical emissions of black and organic carbon aerosol from energy-related combustion, 1850-2000, Global Biogeochem. Cy., 21, GB2018, doi:10.1029/2006GB002840, 2007.

Bouwman, A. F., Lee, D. S., Asman, W. A. H., Dentener, F. J., Van Der Hoek, K. W., and Olivier, J. G. J.: A global high-resolution emission inventory for ammonia, Global Biogeochem. Cy., 11, 561-587, doi:10.1029/97GB02266, 1997.

Carn, S., Krueger, A., Krotkov, N., Yang, K., and Levelt, P.: Sulfur dioxide emissions from Peruvian copper smelters detected by the Ozone Monitoring Instrument, Geophys. Res. Lett., 34, L09801, doi:10.1029/2006GL029020, 2007.

Carn, S., Krueger, A., Arellano, S., Krotkov, N., and Yang, K.: Daily monitoring of Ecuadorian volcanic degassing from space, J. Volcanol. Geotherm. Res., 176, 141-150, 2008.

Carn, S. A., Krueger, A. J., Krotkov, N. A., Yang, K., and Evans, K.: Tracking volcanic sulfur dioxide clouds for aviation hazard mitigation, Nat. Hazards, 51, 325-343, 2009.

Chance, K., Palmer, P. I., Spurr, R. J. D., Martin, R. V., Kurosu, T. P., and Jacob, D. J.: Satellite observations of formaldehyde over North America from GOME, Geophys. Res. Lett., 27, 3461$3464,2000$.

Chin, M., Chu, A., Levy, R., Remer, L., Kaufman, Y., Holben, B., Eck, T., Ginoux, P., and Gao, Q.: Aerosol distribution in the Northern Hemisphere during ACE-Asia: re- sults from global model, satellite observations, and Sun photometer measurements, J. Geophys. Res., 109, D23S90, doi:10.1029/2004JD004829, 2004.

De Smedt, I., Müller, J.-F., Stavrakou, T., van der A, R., Eskes, H., and Van Roozendael, M.: Twelve years of global observations of formaldehyde in the troposphere using GOME and SCIAMACHY sensors, Atmos. Chem. Phys., 8, 4947-4963, doi:10.5194/acp-8-4947-2008, 2008.

Dickerson, R., Li, C., Li, Z., Marufu, L., Stehr, J., McClure, B., Krotkov, N., Chen, H., Wang, P., Xia, X., Ban, X., Gong, F., Yuan, J., and Yang, J.: Aircraft observations of dust and pollutants over northeast China: insight into the meteorological mechanisms of transport, J. Geophys. Res., 112, D24S90, doi:10.1029/2007JD008999, 2007.

Dirksen, R. J., Boersma, K. F., de Laat, J., Stammes, P., van der Werf, G. R., Martin, M. V., and Kelder, H. M.: An aerosol boomerang: rapid around-the-world transport of smoke from the December 2006 Australian forest fires observed from space, J. Geophys. Res, 114, D21201, doi:10.1029/2009JD012360, 2009.

Drury, E., Jacob, D., Wang, J., Spurr, R., and Chance, K.: Improved algorithm for MODIS satellite retrievals of aerosol optical depths over western North America, J. Geophys. Res., 113, D16204, doi:10.1029/2007JD009573, 2008.

Drury, E., Jacob, D. J., Spurr, R. J. D., Wang, J., Shinozuka, Y., Anderson, B. E., Clarke, A. D., Dibb, J., McNaughton, C., and Weber, R.: Synthesis of satellite (MODIS), aircraft (ICARTT), and surface (IMPROVE, EPA-AQS, AERONET) aerosol observations over North America to improve MODIS aerosol retrievals and constrain surface aerosol concentrations and sources, J. Geophys. Res., 115, D14204, doi:10.1029/2009JD012629, 2010.

EDGAR: Emission Database for Global Atmospheric Research (EDGAR), http://www.mnp.nl/edgar/, 2005.

Fairlie, T. D., Jacob, D. J., and Park, R. J.: The impact of transpacific transport of mineral dust in the United States, Atmos. Environ., 41, 1251-1266, doi:10.1016/j.atmosenv.2006.09.048, 2007.

Giglio, L., Randerson, J. T., van der Werf, G. R., Kasibhatla, P. S., Collatz, G. J., Morton, D. C., and DeFries, R. S.: Assessing variability and long-term trends in burned area by merging multiple satellite fire products, Biogeosciences, 7, 1171-1186, doi:10.5194/bg-7-1171-2010, 2010.

Ginoux, P., Chin, M., Tegen, I., Prospero, J. M., Holben, B., Dubovik, O., and Lin, S. J.: Sources and distributions of dust aerosols simulated with the GOCART model, J. Geophys. Res., 106, 20255-20273, doi:10.1029/2004JD004829, 2001.

Ginoux, P., Prospero, J. M., Torres, O., and Chin, M.: Long-term simulation of global dust distribution with the GOCART model: correlation with North Atlantic Oscillation, Environ. Modell. Softw., 19, 113-128, 2004.

Goldstein, A. H., Koven, C. D., Heald, C. L., and Fung, I. Y.: Biogenic carbon and anthropogenic pollutants combine to form a cooling haze over the southeastern United States, PNAS, 106, 8835-8840, doi:10.1073/pnas.0904128106, 2009.

Guenther, A., Karl, T., Harley, P., Wiedinmyer, C., Palmer, P. I., and Geron, C.: Estimates of global terrestrial isoprene emissions using MEGAN (Model of Emissions of Gases and Aerosols from Nature), Atmos. Chem. Phys., 6, 3181-3210, doi:10.5194/acp-63181-2006, 2006.

Hains, J. C., Boersma, K. F., Kroon, M., Dirksen, R., Cohen, R. C., Perring, A. E., Bucsela, E. J., Volten, H., Swart, D. P. J., Richter, 
A., Wittrock, F., Schoenhardt, A., Wagner, T., Ibrahim, O. W., Van Roozendael, M., Pinardi, G., Gleason, J. F., Veefkind, J. P., and Levelt, P. F.: J. Geophys. Res., Testing and improving OMI DOMINO tropospheric $\mathrm{NO}_{2}$ using observations from the DANDELIONS and INTEX-B validation campaigns, 115, D05301, doi:10.1029/2009JD012399, 2010.

Heald, C. L., Jacob, D. J., Turquety, S., Hudman, R. C., Weber, R. J., Sullivan, A. P., Peltier, R. E., Atlas, E. L., De Gouw, J. A., Warneke, C., et al.: Concentrations and sources of organic carbon aerosols in the free troposphere over North America, J. Geophys. Res, 111, D23S47, doi:10.1029/2006JD007705, 2006.

Henze, D. K., Seinfeld, J. H., and Shindell, D. T.: Inverse modeling and mapping US air quality influences of inorganic PM2.5 precursor emissions using the adjoint of GEOS-Chem, Atmos. Chem. Phys., 9, 5877-5903, doi:10.5194/acp-9-58772009, 2009.

Herman, J., Bhartia, P., Torres, O., Hsu, C., Seftor, C., and Celarier, E.: Global distribution of UV-absorbing aerosols from Nimbus 7/TOMS data, J. Geophys. Res., 102, 16911-16922, 1997.

Jacobson, M. Z.: Computation of global photochemistry with SMVGEAR II, Atmos. Environ., 29, 2541-2546, 1995.

Kaufman, Y. J., Tanré, D., and Boucher, O.: A satellite view of aerosols in the climate system, Nature, 419, 215-223, 2002.

Koepke, P., Hess, M., Schult, I., and Shettle, E.: Global Aerosol Data Set, Max-Planck-Institut für Meteorologie, Hamburg, Report No. 243, 1997.

Kopacz, M., Jacob, D. J., Fisher, J. A., Logan, J. A., Zhang, L., Megretskaia, I. A., Yantosca, R. M., Singh, K., Henze, D. K., Burrows, J. P., Buchwitz, M., Khlystova, I., McMillan, W. W., Gille, J. C., Edwards, D. P., Eldering, A., Thouret, V., and Nedelec, P.: Global estimates of CO sources with high resolution by adjoint inversion of multiple satellite datasets (MOPITT, AIRS, SCIAMACHY, TES), Atmos. Chem. Phys., 10, 855-876, doi:10.5194/acp-10-855-2010, 2010.

Krijger, J. M., van Weele, M., Aben, I., and Frey, R.: Technical Note: the effect of sensor resolution on the number of cloud-free observations from space, Atmos. Chem. Phys., 7, 2881-2891, doi:10.5194/acp-7-2881-2007, 2007.

Krotkov, N. A., Carn, S. A., Krueger, A. J., Bhartia, P. K., and Yang, $\mathrm{K}$.: Band residual difference algorithm for retrieval of $\mathrm{SO}_{2}$ from the aura ozone monitoring instrument (OMI), IEEE T. Geosci. Remote, 44, 1259-1266, 2006.

Krotkov, N., McClure, B., Dickerson, R., Carn, S., Li, C., Bhartia, P., Yang, K., Krueger, A., Li, Z., Levelt, P., Chen, H., Wang, P., and $\mathrm{Lu}$, D.: Validation of $\mathrm{SO}_{2}$ retrievals from the Ozone Monitoring Instrument over NE China, J. Geophys. Res., 113, D16S40, doi:10.1029/2007JD008818, 2008.

Krueger, A., Krotkov, N., Yang, K., Carn, S., Vicente, G., and Schroeder, W.: Applications of Satellite-based Sulfur Dioxide Monitoring, IEEE. J. Sel. Top. Appl., 2, 293-298, doi:10.1109/JSTARS.2009.2037334, 2009.

Kurosu, T. P., Liu, X., Celarier, E. A., and Chance, K. V.: Air Quality Observations from the Ozone Monitoring Instrument on EOS/Aura - HCHO and CHO-CHO, Eos Trans. AGU, 89(23), Jt. Assem. Suppl., Abstract A23A-05, 2008.

Lamsal, L. N., Martin, R. V., van Donkelaar, A., Celarier, E. A., Bucsela, E. J., Boersma, K. F., Dirksen, R., Luo, C., and Wang, Y.: Indirect validation of tropospheric nitrogen dioxide retrieved from the OMI satellite instrument: insight into the seasonal vari- ation of nitrogen oxides at northern midlatitudes, J. Geophys. Res., 115, D05302, doi:10.1029/2009JD013351, 2010.

Lee, C., Martin, R., van Donkelaar, A., O’Byrne, G., Krotkov, N., Richter, A., Huey, G., and Holloway, J.: Retrieval of vertical columns of sulfur dioxide from SCIAMACHY and OMI: air mass factor algorithm development, validation, and error analysis, J. Geophys. Res., 114, D22303, doi:10.1029/2009JD012123, 2009.

Levelt, P. F., van den Oord, G. H. J., Dobber, M. R., Malkki, A., Visser, H., de Vries, J., Stammes, P., Lundell, J. O. V., and Saari, H.: The ozone monitoring instrument, IEEE T. Geosci. Remote, 44, 1093-1101, 2006.

Levy, R. C., Remer, L. A., Kleidman, R. G., Mattoo, S., Ichoku, C., Kahn, R., and Eck, T. F.: Global evaluation of the Collection 5 MODIS dark-target aerosol products over land, Atmos. Chem. Phys., 10, 10399-10420, doi:10.5194/acp-10-10399-2010, 2010.

Li, C., Zhang, Q., Krotkov, N., Streets, D., He, K., Tsay, S.C., and Gleason, J.: Recent large reduction in sulfur dioxide emissions from Chinese power plants observed by the Ozone Monitoring Instrument, Geophys. Res. Lett., 37, L08807, doi:10.1029/2010GL042594, 2010.

Liu, H., Jacob, D. J., Bey, I., and Yantosca, R. M.: Constraints from ${ }^{210} \mathrm{~Pb}$ and ${ }^{7} \mathrm{Be}$ on wet deposition and transport in a global three-dimensional chemical tracer model driven by assimilated meteorological fields, J. Geophys. Res., 106, 12-109, 2001.

Liu, Y., Sarnat, J. A., Coull, B. A., Koutrakis, P., and Jacob, D. J.: Validation of Multiangle Imaging Spectroradiometer (MISR) aerosol optical thickness measurements using Aerosol Robotic Network (AERONET) observations over the contiguous United States, J. Geophys. Res., 109, D06205, doi:10.1029/2003JD003981, 2004.

Lohmann, U. and Feichter, J.: Global indirect aerosol effects: a review, Atmos. Chem. Phys., 5, 715-737, doi:10.5194/acp-5-7152005, 2005.

Martin, R. V., Jacob, D. J., Yantosca, R. M., Chin, M., and Ginoux, P.: Global and regional decreases in tropospheric oxidants from photochemical effects of aerosols, J. Geophys. Res., 108, 4537, doi:10.1029/2003JD003453, 2003.

Martin, R. V., Sioris, C. E., Chance, K., Ryerson, T. B., Bertram, T. H., Wooldridge, P. J., Cohen, R. C., Neuman, J. A., Swanson, A., and Flocke, F. M.: Evaluation of space-based constraints on global nitrogen oxide emissions with regional aircraft measurements over and downwind of eastern North America, J. Geophys. Res., 111, D15308, doi:10.1029/2005JD006680, 2006.

Millet, D., Jacob, D., Boersma, F., Fu, T.-M., Kurosu, T., Chance, K., Heald, C., and Guenther, A.: Spatial distribution of isoprene emissions from North America derived from formaldehyde column measurements by the OMI satellite sensor, J. Geophys. Res., 113, D02307, doi:10.1029/2007JD008950, 2008.

Palmer, P. I., Jacob, D. J., Chance, K., Martin, R. V., Spurr, R. J. D., Kurosu, T. P., Bey, I., Yantosca, R., Fiore, A., and Li, Q.: Air mass factor formulation for spectroscopic measurements from satellites: application to formaldehyde retrievals from GOME, J. Geophys. Res., 106, 14539-14550, doi:10.1029/2000JD900772, 2001.

Park, R. J., Jacob, D. J., Field, B. D., Yantosca, R. M., and Chin, M.: Natural and transboundary pollution influences on sulfate-nitrate-ammonium aerosols in the United States: Implications for policy, J. Geophys. Res., 109, D15204, 
doi:10.1029/2003JD004473, 2004.

Remer, L. A., Kaufman, Y. J., Tanré, D., Mattoo, S., Chu, D. A., Martins, J. V., Li, R. R., Ichoku, C., Levy, R. C., Kleidman, R. G., Eck, T. F., Vermote, E., and Holben, B. N.: The MODIS aerosol algorithm, products, and validation, J. Atmos. Sci., 62, 947-973, 2005.

Solomon, S., Qin, D., Manning, M., Chen, Z., Marquis, M., Averyt, K. B., Tignor, M., and Miller, H. L.: Climate change 2007: the physical science basis, Cambridge University Press, New York, 2007.

Stokes, G. M. and Schwartz, S. E.: The Atmospheric Radiation Measurement (ARM) Program: programmatic background and design of the cloud and radiation test bed, B. Am. Meteorol. Soc., 75, 1201-1222, 1994.

van Donkelaar, A., Martin, R. V., Leaitch, W. R., Macdonald, A. M., Walker, T. W., Streets, D. G., Zhang, Q., Dunlea, E. J., Jimenez, J. L., Dibb, J. E., Huey, L. G., Weber, R., and Andreae, M. O.: Analysis of aircraft and satellite measurements from the Intercontinental Chemical Transport Experiment (INTEX-B) to quantify long-range transport of East Asian sulfur to Canada, Atmos. Chem. Phys., 8, 2999-3014, doi:10.5194/acp-8-2999-2008, 2008.

Wang, J., Jacob, D. J., and Martin, S. T.: Sensitivity of sulfate direct climate forcing to the hysteresis of particle phase transitions, J. Geophys. Res, 113, D11207, doi:10.1029/2007JD009368, 2008.

Wang, J., Remer, L. A., Colarco, P., Eck, T. F., and Shell, K.: http: //acmg.seas.harvard.edu/geos/geos_meeting_2009.html, 2009.

Wang, J., Spurr, R. J. D., Wang, Y., and Drury, E.: Improved algorithm for MODIS satellite retrievals of aerosol optical thickness over land in dusty atmosphere: Implications for air qquality monitoring in China, Remote Sens. Environ., 114, 2575-2583, doi:10.1016/j.rse.2010.05.034, 2010.
Witte, J., Schoeberl, M., Douglass, A., Gleason, J., Krotkov, N., Gille, J., Pickering, K., and Livesey, N.: Satellite observations of changes in air quality during the 2008 Beijing Olympics and Paralympics, Geophys. Res. Lett., 36, L17803, doi:10.1029/2009GL039236, 2009.

Xue, L., Ding, A., Gao, J., Wang, T., Wang, W., Wang, X., Lei, H., Jin, D., and Qi, Y.: Aircraft measurements of the vertical distribution of sulfur dioxide and aerosol scattering coefficient in China, Atmos. Environ., 44(2), 278-282, 2009.

Yang, K., Krotkov, N., Krueger, A., Carn, S., Bhartia, P., and Levelt, P.: Retrieval of large volcanic $\mathrm{SO}_{2}$ columns from the Aura Ozone Monitoring Instrument: comparison and limitations, J. Geophys. Res., 112, D24S43, doi:10.1029/2007JD008825, 2007.

Yang, K., Krotkov, N., Krueger, A., Carn, S., Bhartia, P., and Levelt, P.: Improving retrieval of volcanic sulfur dioxide from backscattered UV satellite observations, Geophys. Res. Lett., 36, L03102, doi:10.1029/2008GL036036, 2009a.

Yang, K., Liu, X., Krotkov, N., Krueger, A., and Carn, S.: Estimating the altitude of volcanic sulfur dioxide plumes from space borne hyper-spectral UV measurements, Geophys. Res. Lett., 36, L10803, doi:10.1029/2009GL038025, 2009b.

Yu, H., Kaufman, Y. J., Chin, M., Feingold, G., Remer, L. A., Anderson, T. L., Balkanski, Y., Bellouin, N., Boucher, O., Christopher, S., DeCola, P., Kahn, R., Koch, D., Loeb, N., Reddy, M. S., Schulz, M., Takemura, T., and Zhou, M.: A review of measurement-based assessments of the aerosol direct radiative effect and forcing, Atmos. Chem. Phys., 6, 613-666, doi:10.5194/acp-6-613-2006, 2006.

Zender, C. S., Bian, H., and Newman, D.: Mineral Dust Entrainment and Deposition (DEAD) model: Description and 1990s dust climatology, J. Geophys. Res., 108, 4416, doi:10.1029/2002JD002775, 2003. 